\title{
'Karima-1': Dry Pea Cultivar for Canning in the Sudan
}

\section{G.H. Mohamedali ${ }^{1}$ and A.H. Nourai \\ Hudeiba Research Station, P.O. Box 31, Ed-Damer, Sudan}

Additional index words. Pisum sativum, vegetable breeding, Erysiphe polygoni

In Sudan, dry peas (Pisum sativum L.) are produced in the northern state, predominantly as a winter crop, from November to February. Production for canning is expanding to cover the needs of two canning plants (Nourai et al., 1983). The canning industry was confined to using local types that are late, heterogeneous, and low yielding. The two introduced American cultivars Alaska and Nome, recommended by the Agricultural Research Corporation, are high in quality but are low yielding. Thus, a breeding program was initiated to develop high-yielding genotypes that possess acceptable processing quality.

A breeding selection program was initiated from 1978 to 1979 at Hudeiba Research Station (lat. $17^{\circ} 34^{\prime} \mathrm{N}$, long. $33^{\circ} 56^{\prime} \mathrm{E} ; 350-\mathrm{m}$ elevation) in the northern region of Sudan. The soils at Hudeiba are aridsols, heavy-textured, calcareous, alkaline old soils that crack easily due to their appreciable mortmorillonitic clay content. They are low in organic matter and relatively poor in $\mathrm{N}$. The climate is tropical and arid, but it is relatively cool in winter from November to February, with day/night means of $32 / 15 \mathrm{C}$ and 11.0 to $11.5 \mathrm{~h}$ of daylength. Rainfall ( 0 to $200 \mathrm{~mm}$ ) occurs mainly between July and September.

\section{Origin}

In 1974, a dry-pea germplasm collection with 580 entries was received from the International Center for Agricultural Research in the Dry Areas (ICARDA), Aleppo, Syria. Initial screening, performed in two seasons (197879 and 1979-80), resulted in the elimination of 520 entries because they were either maladapted to the local environment, susceptible to powdery mildew (Erysiphe polygoni DC), or of poor seed quality. The standard single plant selection approach (pedigree method) was followed to eliminate within-entry variability and select high-yielding lines with acceptable canning qualities. Four generations of selection were necessary to obtain pure lines (1982-83 season).

'Karima-1' was developed as an $\mathrm{F}_{4}$ selection from entry 590 ( 590 was the number given

Received for publication 12 July 1993 . Accepted for publication 23 Apr. 1994. This research was funded by Agricultural Research Corp.; International Development Research Center, Canada; and International Fund for Agricultural Development. The cost of publishing this paper was defrayed in part by the payment of page charges. Under postal regulations, this paper therefore must be hereby marked advertisement solely to indicate this fact.

${ }^{1}$ Current address: National Center for Seed Multiplication, P.O. Box 9088, Seiyun, Republic of Yemen.

Fig. 1. Pedigree of 'Karima-1'. to $1989-90$

${ }^{x}$ Each mean is based on four replications. 1986-87 to 1989-90.

${ }^{\mathrm{z}}$ Each mean is based on six replications. by ICARDA), which is a local Syrian-type variable in seed size, color, and shape. It was carried as a bulk line though $\mathrm{F}_{6}$ and officially released to the canning industry in Sudan in 1989 (Mohamedali, 1989) (Fig. 1).

Testsfor yield and canning qualities. Breeding lines were assessed for seed yield and canning qualities for four seasons (1986 to 1990) using the American cultivars Alaska and Nome as controls; both cultivars generally are suited for canning. Quality assessment included percentage of nonsoakers (NS) after 12-h soaking in tap water, hydration coefficient (HC; weight of seeds after 12-h soaking $\div$ weight of seeds before soaking $\times 100$ ), percent increase in weight after processing (IWP) compared to that after 12-h soaking, time for processing (TP), and protein percentage as determined by the Kjeldahl method.

'Karima-1' was consistently high yielding, having a seed yield advantage ranging from $174 \%$ to $594 \%$ over 'Alaska' (Table 1). The high-yielding capacity of 'Karima-1' is derived primarily from the many pods produced per plant, averaging 14 for 'Karima-1' vs. seven for 'Alaska'. Seed yield had a significant positive correlation with the number of pods produced per plant $(r=0.72)$. 'Karima- 1 ' may be more adapted to the relatively high temperatures during the growing season than 'Alaska' and 'Nome'; it has a higher harvest index, lower NS, and a higher HC and IWP compared to either 'Alaska' or 'Nome'. Its protein content and time needed for processing are similar to those of 'Alaska' and 'Nome' (Tables 1 and 2).

\section{Description}

The 'Karima-1' plant has a tall (60 to 80 $\mathrm{cm})$, indeterminate, dark-green vine. Growth is vigorous with standard leaf size and morphology. The leaf is acute $\left(45^{\circ}\right)$, and the cultivar has a basal kind of branching beginning 3 to $5 \mathrm{~cm}$ above the ground. Flowers are white. The cultivar needs 37, 44, and 94 days to flower, pod, and mature, respectively, when planted during the third week of November on ridges $60 \mathrm{~cm}$ apart, seeds sown in two rows per ridge in hills $10 \mathrm{~cm}$ apart, each with three plants.

Pods are dark green, with blunt edges and are produced individually at each node. Average pod length is $8 \pm 2 \mathrm{~cm}$, and width is $1.5 \pm$ $0.2 \mathrm{~cm}$. An average of eight to 18 pods are produced per plant, with each pod containing four to five seeds. The 1000-seed weight is 195 $\pm 20 \mathrm{~g}$. Seeds are large, wrinkled, green, and assume a uniform green, large, smooth shape after processing (John Innes Institute, 1986).

\section{Availability}

'Karima-1' seeds can be requested from G.H.M. for experimental purposes. For commercial-size lots, contact the Director General, Agricultural Research Corporation, WadMedani, Sudan.

\section{Literature Cited}

John Innes Institute. 1986. John Innes Pisum germplasm collection. Phenotype/evaluation descriptors. John Innes Inst., Norwich, U.K.

Mohamedali, G.H. 1989. Karima-1, A new dry pea (Pisum sativum L.) variety for canning in the Sudan. Technical Committee for Variety Release. Agr. Res. Corp., WadMedani, Sudan.

Nourai, A.H., G.H. Mohamedali, and A.A. ElMotasim. 1983. A review of research on pea (Pisum sativum L.) in the Sudan. Agr. Res. Corp., Ed Damer, Sudan.

$\mathrm{F}_{4} \quad \mathrm{X} \underset{\text { development }}{\stackrel{\text { Bulk line }}{\longrightarrow}} \mathrm{F}_{6}{ }^{\prime}$ Karima-1'

Table 1. Comparison of 'Karima-1' with 'Alaska' and 'Nome' for yield at Hudeiba, Sudan, from 1986-87

\begin{tabular}{|c|c|c|c|c|c|}
\hline \multirow[b]{3}{*}{ Entry } & \multicolumn{4}{|c|}{ Yield $\left(\mathrm{t} \cdot \mathrm{ha}^{-1}\right)$} & \multirow{3}{*}{$\begin{array}{c}\text { Harvest } \\
\text { index }(\%)^{z}\end{array}$} \\
\hline & \multicolumn{4}{|c|}{ Season } & \\
\hline & 1986-87 & $1987-88$ & 1988-89 & 1989-90 & \\
\hline Karima-1 & $3.44(174)^{y}$ & $1.50(250)$ & $2.89(185)$ & $1.01(594)$ & 52 \\
\hline Alaska & 1.98 & 0.60 & 1.56 & 0.17 & 37 \\
\hline Nome & 1.77 (89) & $0.50(83)$ & $1.61(103)$ & 0.19 (112) & 38 \\
\hline $\operatorname{LSD}_{(0.05)} \mathrm{x}$ & 0.85 & 0.60 & 0.79 & 0.41 & 5 \\
\hline
\end{tabular}

${ }^{\mathrm{z}}$ Harvest index $=[$ seed yield/biological yield $($ seed + straw $)] \times 100 ;$ measured at harvest.

y Numbers in parentheses are yields as percentage of the 'Alaska' control.

Table 2. Comparison of 'Karima-1' with 'Alaska' and 'Nome' for canning qualities at Hudeiba, Sudan, from

\begin{tabular}{lccccc}
\hline \hline Entry & $\begin{array}{c}\text { Hydration } \\
\text { consoakers } \\
(\%)\end{array}$ & $\begin{array}{c}\text { Wt increase } \\
\text { after processing }\end{array}$ & $\begin{array}{c}\text { Time for } \\
\text { processing } \\
(\%)\end{array}$ & $\begin{array}{c}\text { (min) } \\
\text { Protein }\end{array}$ & $\begin{array}{c}\text { Prin } \\
(\%)\end{array}$ \\
\hline Karima-1 & 9 & 251 & 37 & 15 & 24.6 \\
Alaska & 12 & 213 & 14 & 13 & 25.4 \\
Nome & 12 & 221 & 13 & 14 & 25.9 \\
LSD $_{(0.05)}{ }^{\mathrm{z}}$ & 7 & 14 & 11 & 3 & 1.2 \\
\hline
\end{tabular}

